\title{
EFFECTS OF LONG-TERM LIVESTOCK GRAZING AND HABITAT ON UNDERSTORY VEGETATION
}

\author{
Jonathan D. Bakker ${ }^{1}$, Faith Rudebusch ${ }^{2}$, and Margaret M. Moore ${ }^{3}$
}

\begin{abstract}
The herbaceous understory stratum contains most of the plant diversity in ponderosa pine (Pinus ponderosa P. \& C. Lawson var. scopulorum Engelm.) forests of the American Southwest and provides critical food and habitat for many wildlife species. During the last century, this stratum has been affected by livestock grazing and by increased dominance of overstory trees. We sampled a unique grazing exclosure to examine the relative importance of long-term livestock grazing (grazed or ungrazed) and habitat (park or tree) on the understory community. We sampled 3 plots of 192 contiguous quadrats (each quadrat $0.5 \mathrm{~m}^{2}$ ) in each of the 4 treatment combinations, for a total of 2304 quadrats. Species-area curves were generated by aggregating quadrats into nonoverlapping areas at grain sizes of 0.5 to $576 \mathrm{~m}^{2}$. The effects of habitat and grazing on species density were evident at very different scales. Species density was higher in park than tree plots at scales $\leq 32 \mathrm{~m}^{2}$ but did not differ between habitats at larger scales. Species density differed minimally between grazed and ungrazed treatments at small grains, but grazed plots contained more species than ungrazed plots at larger grains. Grazing treatments differed at smaller grains (to 4-8 $\mathrm{m}^{2}$ ) than did habitats (to $32 \mathrm{~m}^{2}$ ), with respect to density of native species and graminoids. Grazed plots had more exotic species than ungrazed plots at all grain sizes, though few exotics were present. Twenty-two species were identified as indicator species associated with habitats and/or grazing treatments. Evaluations of plant community response to treatments would be improved by accounting for the grain at which data have been collected and analyzed and by identifying indicator species associated with various treatments. These data would enable more-informed conservation and management decisions.
\end{abstract}

Key words: Pinus ponderosa, livestock grazing, species-area curves, indicator species analysis, Hill plots.

Ponderosa pine (Pinus ponderosa C. Lawson var. scopulorum Engelm.) forests of the American Southwest are increasingly recognized to be at risk of wildfire, insect outbreaks, and other disturbances (Covington and Moore 1994, Allen et al. 2002). These risks have stimulated much research about the woody overstory vegetation. Much less attention has been focused on the herbaceous understory vegetation (Arnold 1950, Milchunas 2006, Bakker and Moore 2007). However, the understory stratum contains most of the plant diversity in these ecosystems and provides food and habitat for many wildlife species. Conservation of ponderosa pine-bunchgrass ecosystems, therefore, requires a careful assessment of the factors affecting the understory. In these forests, 2 notable factors are livestock grazing and increased dominance by overstory trees during the 20th century (Moore and Deiter 1992, Fleischner 1994, Laughlin et al. 2006, Moore et al. 2006).

Livestock grazing is common in the western United States, where approximately $70 \%$ of the area is used for livestock production
(Fleischner 1994). Quantifying the effects of livestock grazing can be difficult due to the sparsity of ungrazed control areas, though livestock exclosures provide one way to do so (Courtois et al. 2004, Loeser et al. 2004). Unlike relict areas, where geographic features prevent livestock access, exclosures can be established experimentally in areas that are accessible to livestock and therefore have comparable land-use histories (Bakker and Moore 2007).

Fire suppression resulted in dramatic increases in the overstory within southwestern ponderosa pine forests during the early to mid-20th century (Cooper 1960). Negative overstory-understory correlations have been recognized by range scientists for decades (Arnold 1950, Moore and Deiter 1992) but have generally not been explicitly accounted for in the modeling of understory dynamics in these forests (Bakker 2005). However, information on overstory-understory relationships can be of critical importance for predicting understory response to overstory reductions

\footnotetext{
${ }^{1}$ School of Forest Resources, University of Washington, Box 354115, Seattle, WA 98195-4115. E-mail: jbakker@u.washington.edu

${ }^{2}$ Ecological Restoration Institute, Northern Arizona University, Box 15017, Flagstaff, AZ 86011-5017.

${ }^{3}$ School of Forestry, Northern Arizona University, Box 15018, Flagstaff, AZ 86011-5018.
} 


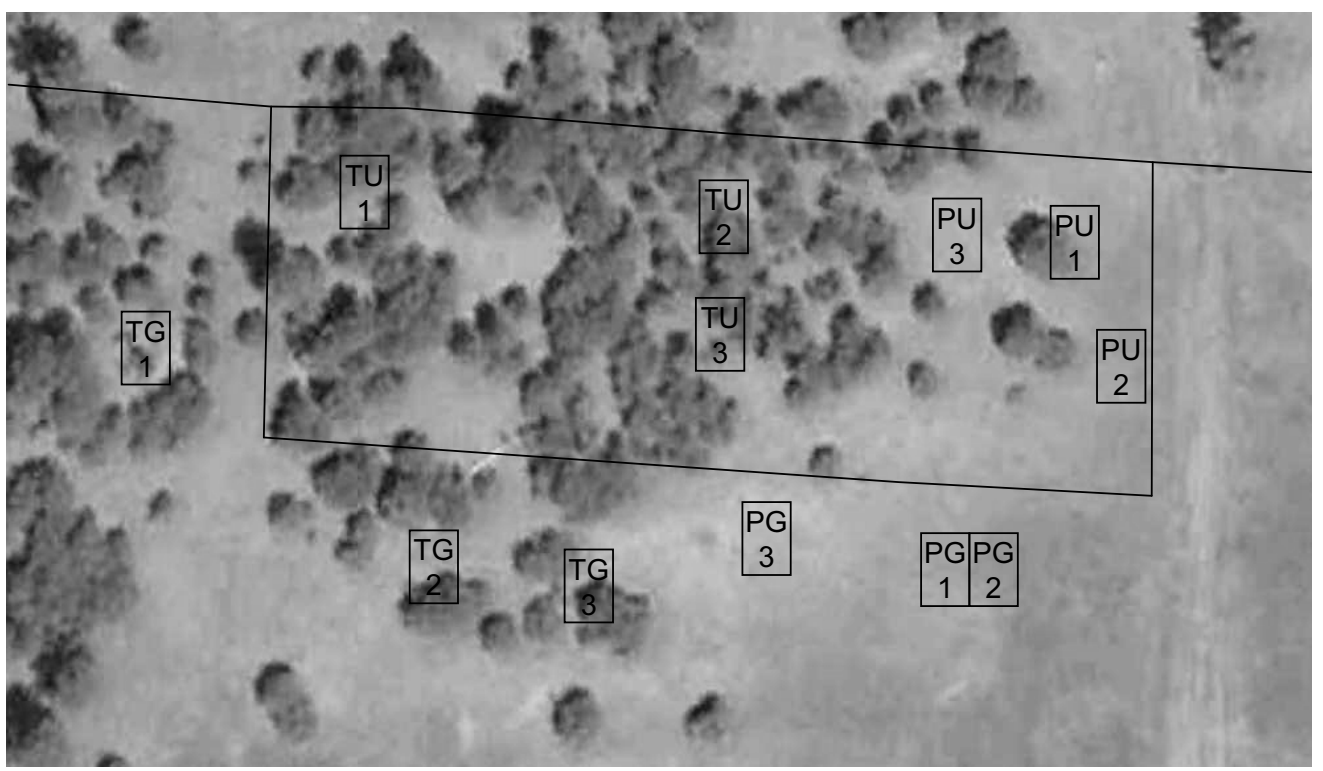

Fig. 1. Location of the Fry Park exclosure, showing the tree and park habitats and the grazing exclosure (fences are indicated by black lines). Three plots were established in each of 4 treatment combinations: park grazed (PG), park ungrazed (PU), tree grazed (TG), and tree ungrazed (TU). The exclosure was established in 1912, and the plots were measured in 2005. The aerial photo was taken in 2005.

and other management activities (Moore et al. 2006, Bakker and Moore 2007).

In this study, our objective was to examine the relative importance of livestock grazing (ongoing livestock grazing or long-term [93-year] protection from grazing) and habitat (park [montane grassland] or tree [forest]) to herbaceous understory in ponderosa pine forests. Because the conclusions of a study can be affected by the choice of response variable (Laughlin et al. 2006) and the spatial scale at which analyses occur (Condit et al. 1996, Colwell et al. 2004), we focused on aerial cover and species density (the number of species per sample unit; Gotelli and Colwell 2001) at various grain sizes. However, these variables ignore compositional differences that may be important in explaining differences among treatments, so we also identified individual species that were indicative of the treatments (Bakker 2008).

\section{Methods \\ Study Area}

In 1912, livestock grazing exclosures were established at 5 sites in northern Arizona. Collectively, these sites are known as the Hill plots (Arnold 1950, Baker and Moore 2007). Our high sampling intensity and logistic constraints required that we focus on a single site, Fry Park. Fry Park is $20 \mathrm{~km}$ southwest of Flagstaff, Arizona $\left(35^{\circ} 4^{\prime} \mathrm{N}, 111^{\circ} 47^{\prime} \mathrm{W}\right)$ at $2170 \mathrm{~m}$ elevation. Its exclosure is 0.8 ha $(55 \times 143 \mathrm{~m})$ and spans the ecotonal boundary between the park and tree habitats (Fig. 1). This ecotone appears to have been fairly stable over the last century (data not shown). Key reasons for its maintenance may include climatic conditions (cold-air drainage into parks) and fine-textured soils (Coop and Givnish 2007).

Our study was conducted within and immediately adjacent to the livestock exclosure at Fry Park. We acknowledge that this study is therefore pseudoreplicated (Hurlbert 1984), though the resulting data are still worthy of consideration (Oksanen 2001). Hargrove and Pickering (1992:251) note that "there is conflict between the need to replicate and the need to study processes at appropriately large scales." We would add that this conflict also affects decisions about sampling intensity. Furthermore, studies of individual exclosures like ours can provide valuable data for future meta-analyses. Examples of comparable single-site studies include Oesterheld and Sala (1990), Carmel and Kadmon (1999), Green et al. (2003), and Ruthven (2007). 
The Fry Park area was selectively logged in 1910 (Arnold 1950). Tree density did not differ between grazing treatments when the exclosure was established but is currently greater inside than outside the exclosure (inside: 451 trees $\cdot \mathrm{ha}^{-1}$; outside: 136 trees $\cdot \mathrm{ha}^{-1}$; Bakker and Moore 2007) due to differential recruitment and survival of pine regeneration. Ponderosa pine is the only tree species at the study site. The understory herbaceous vegetation is dominated by perennial grasses, such as Sporobolus interruptus Vasey, Poa fendleriana (Steud.) Vasey, and Muhlenbergia montana (Nutt.) Hitchc. Soils are Typic Argiborolls with basalt/cinder parent materials (Miller et al. 1995).

Cattle have grazed Fry Park since the late 1800 s, though the exclosure has been maintained since 1912. Currently, grazing occurs for a few weeks each summer. In 2005, cattle were permitted to graze the area from 13 August to 7 September at an intensity of 0.03 animal unit months per hectare (USFS 2005); this intensity is much lower than in the early 1900s (see Bakker and Moore [2007] for grazing history details). Wildlife (elk, deer, small mammals) are able to graze inside and outside the exclosure.

\section{Sampling Design}

Sampling occurred in all 4 combinations of grazing treatment (grazed vs. ungrazed) and habitat (park vs. tree) (Fig. 1). Three plots, each $8 \times 12 \mathrm{~m}$, were established in each treatment combination. Plots were randomly located within the exclosure and paired with plots outside the exclosure according to elevation, soil type, depth to bedrock, and tree size, density, and spatial arrangement.

The ground-level diameter of each tree taller than breast height $(1.37 \mathrm{~m}$ above ground level) was measured, and the total tree basal area at ground level was calculated for each plot. Tree canopy cover and litter depth were measured on a $2 \times 2$-m grid across each plot (35 points per plot). Canopy cover was measured using a densitometer at each grid point and calculated as the proportion of points directly beneath a tree crown. Litter depth was measured in $\mathrm{cm}$ and averaged to yield a mean value per plot.

Each plot was divided into 192 quadrats, each $1 \times 0.5 \mathrm{~m}$, for a total of 2304 quadrats. In each quadrat, covers of plants and substrates were measured using modified Daubenmire cover classes: $0-0.25 \%, 0.25-1 \%, 1-5 \%, 5-25 \%$, $25-50 \%, 50-75 \%, 75-95 \%$, and $95-100 \%$ (Magurran 2004); all observations were assigned a cover equal to the midpoint of their cover class. The aerial cover of each plant species was estimated, as were covers of 6 substrate categories (litter, bole of trees and seedlings, bare soil, rocks, wood, and herbaceous plant basal cover). Substrates were estimated independently of plant aerial cover.

Data were collected from 15 to 25 August 2005. To minimize bias among botanists, we established 3 crews of 2 botanists each, and each crew measured one plot per treatment. Unknown specimens were collected and identified at the Deaver Herbarium, Northern Arizona University, Flagstaff, Arizona. Nomenclature and species origin (native vs. exotic) follow the USDA PLANTS database (USDA-NRCS 2006). Plants were also classified by functional group (graminoid vs. forb).

\section{Data Analyses}

Plot conditions were characterized by substrate composition (a matrix of the 6 substrate categories), tree basal area, tree canopy cover, litter depth, and aerial plant cover (total, a matrix of species origins, and a matrix of functional groups). Data were averaged within each plot, and the 12 plots were used as replicates for analyses. Each variable or matrix was analyzed separately using permutational MANOVA (PERMANOVA; Anderson 2001, McArdle and Anderson 2001) to test the effects of grazing, habitat, and the grazing $\times$ habitat interaction. This technique avoids assumptions about data normality and provides a common framework for multi- and univariate analyses. PERMANOVAs were conducted with the Bray-Curtis distance measure using the adonis function in the VEGAN package of $\mathrm{R}$.

Since our quadrats were contiguous and spatially autocorrelated, it would have been inappropriate to develop species-accumulation curves which assume a random sample of quadrats (Colwell et al. 2004). Instead, we followed Condit et al. (1996) and generated species-area curves by aggregating quadrats into nonoverlapping sampling areas at a range of grain sizes $\left(\mathrm{m}^{2}\right): 0.5,1,2,4,8,16,32,64,96$ (one plot), 288 (all 3 plots in a given combination of habitat and grazing treatment), and 576 (all 6 plots in a given habitat or grazing treatment). The 
TABLE 1. Substrates, tree basal area, tree canopy cover, and litter depth in each combination of habitat and grazing treatment at Fry Park, northern Arizona. PERMANOVAs indicate that substrate composition (multivariate) and the 3 univariate responses all differed significantly between habitats $(P \leq 0.05)$ but not between grazing treatments.

\begin{tabular}{|c|c|c|c|c|}
\hline & \multicolumn{2}{|c|}{ Park } & \multicolumn{2}{|c|}{ Tree } \\
\hline & Grazed & Ungrazed & Grazed & Ungrazed \\
\hline \multicolumn{5}{|l|}{ Substrates $(\%)$} \\
\hline Litter & 38 & 55 & 81 & 89 \\
\hline Bare soil & 46 & 31 & 6 & 5 \\
\hline Plant basal cover & 27 & 29 & 4 & 1 \\
\hline Rock & 0 & 1 & 8 & 1 \\
\hline Bole & 0 & 0 & 1 & 1 \\
\hline Wood & 0 & 0 & 2 & 0 \\
\hline Tree basal area $\left(\mathrm{m}^{2} \cdot \mathrm{ha}^{-1}\right)^{\mathrm{a}}$ & 0 & 0 & 66.2 & 75.2 \\
\hline Tree canopy cover $(\%)$ & 0 & 4 & 55 & 63 \\
\hline Litter depth $(\mathrm{cm})$ & 0.22 & 0.68 & 1.96 & 2.54 \\
\hline
\end{tabular}

number of replicates obviously declined as grain size increased. At the $64-\mathrm{m}^{2}$ grain, the sampling area was defined as the $8 \times 8$-m northern extent of each plot; at all other grain sizes, every quadrat was assigned to one nonoverlapping sampling area. Species density was calculated at each grain size and summarized by means and $95 \%$ confidence intervals following Condit et al. (1996).

Indicator species were identified using indicator species analysis (ISA; Dufrêne and Legendre 1997). ISA accounts for the relative abundance (measured as aerial cover) and frequency of each species and is calculated independently for each species. Formulae are described by Dufrêne and Legendre (1997), McCune and Grace (2002), and Bakker (2008). ISAs were conducted using quadrat-level cover data. Separate ISAs were conducted to identify indicators of grazing treatments and of habitats. Analyses of indicator species of grazing treatment were conducted separately for each pair of plots (one inside and one outside the exclosure with similar soils, overstory, elevation, etc.). Analyses of indicator species of habitat were conducted separately for each grazing treatment. By conducting analyses in this fashion, we controlled one factor while assessing differences in the other factor. Results were then combined using meta-analytic techniques (see Bakker 2008) to yield a mean indicator value (IV) and combined $P$ value for each species in each level of each factor. Species were considered to be indicators if mean IV $\geq 25$ and combined $P \leq 0.05$. ISAs were conducted using a routine written for $\mathrm{R}$ (Bakker 2008).

\section{REsults}

\section{General Plot Conditions}

Substrate composition varied between habitats but not between grazing treatments (Table 1). Litter composed most of the substrate in tree plots, while bare soil and herbaceous plant basal cover dominated park plots. Average litter depth was more than 3 times higher in tree than park plots. As expected, tree basal area and canopy cover were substantial in tree plots and negligible in park plots.

Total plant cover was much higher in park than tree plots (Fig. 2). Native species dominated the cover and were most abundant in park habitat, while exotic species were most prevalent in grazed park plots. Graminoid cover was higher in park than tree plots, while forb cover did not differ among treatments.

\section{Species-Area Curves}

We identified 98 species in our study area. At grains up to $32 \mathrm{~m}^{2}$, total species density was higher in park than tree plots and in grazed than ungrazed plots. However, speciesarea curves differed between habitats and grazing treatments (Fig. 3). Habitats differed strongly at small grain sizes but converged at large grains, whereas grazed and ungrazed plots did not differ as strongly at small grains but diverged as sampling area increased. A comparison of species densities at the 2 largest grains shows that species were accumulating more rapidly in the grazed area $\left(12.3 \mathrm{~m}^{2}\right.$. species $\left.{ }^{-1}\right)$ than the ungrazed area $\left(18.6 \mathrm{~m}^{2}\right.$. species $^{-1}$ ). Furthermore, $95 \%$ of the species identified in this study were present in the 

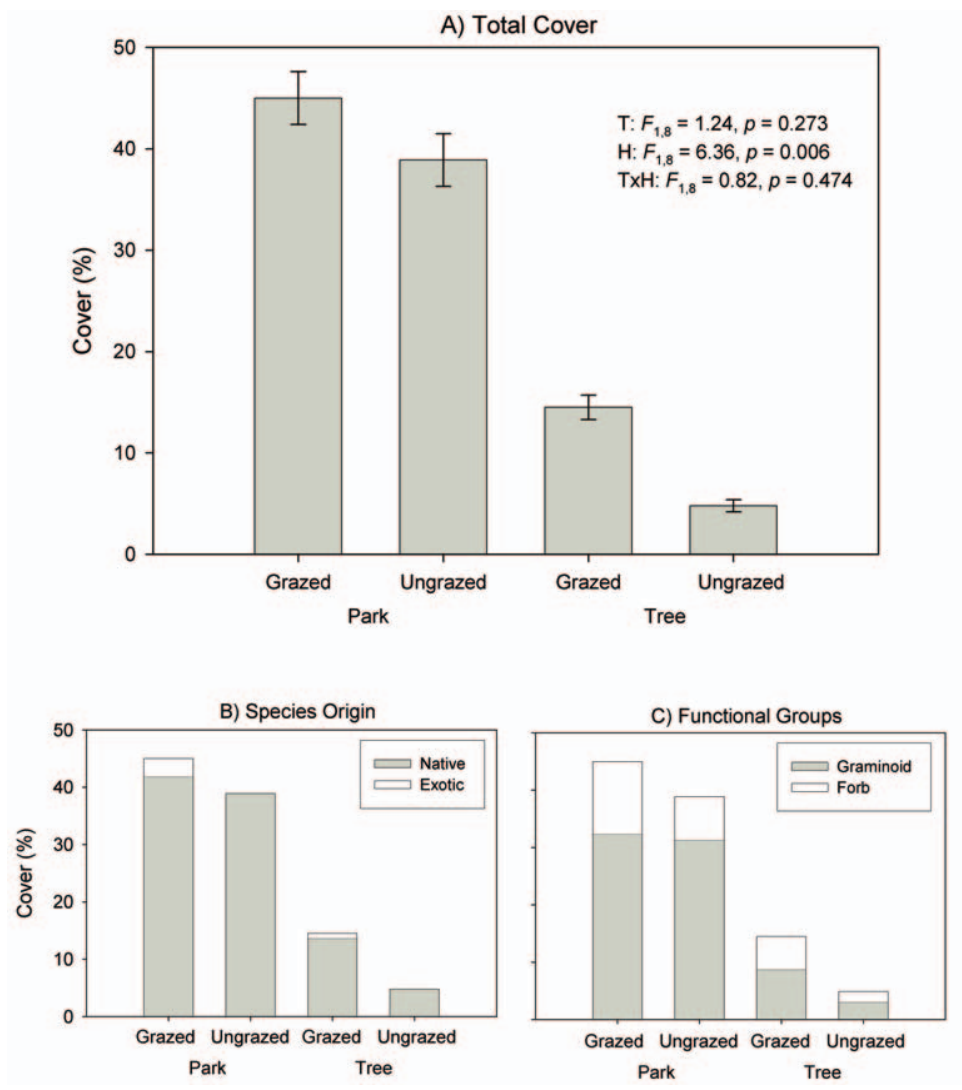

Fig. 2. (A) Average total plant cover (whisker bars indicate $95 \%$ confidence intervals), (B) plant cover by species origin, and (C) plant cover by functional group in grazed and ungrazed areas of park and tree habitats. The results of a PERMANOVA of the effects of grazing treatment $(\mathrm{T})$, habitat $(\mathrm{H})$, and the grazing $\times$ habitat interaction $(\mathrm{T} \times \mathrm{H})$ are shown for total plant cover; similar trends occurred for the matrix of species origins and for the matrix of functional groups.

grazed area, whereas only $66 \%$ were present in the ungrazed area.

Density of native species was higher in park than tree plots at grains $\leq 32 \mathrm{~m}^{2}$ (Fig. 4A). Grazing affected native species density only at very small grains $\left(\leq 4 \mathrm{~m}^{2}\right)$, and the difference between grazing treatments at these grains was much less than the difference between habitats.

Only 7 exotic species were encountered during our sampling. Park plots contained more exotic species than tree plots at grains $\leq 8 \mathrm{~m}^{2}$, whereas grazed plots contained more exotic species than ungrazed plots at all grains (Fig. 4B).

Density of graminoid species was higher in park than tree plots at grain sizes $\leq 32 \mathrm{~m}^{2}$ and in grazed than ungrazed plots at grains $\leq 8 \mathrm{~m}^{2}$ (Fig. $4 \mathrm{C})$. Density of forbs was higher in park than tree plots at grains $\leq 16 \mathrm{~m}^{2}$ and in grazed than ungrazed plots at grains $\leq 32 \mathrm{~m}^{2}$ (Fig. 4D).

\section{Indicator Species}

Twenty-two species were indicators of habitat and/or grazing treatment (Table 2). Thirteen of 15 habitat indicators were indicators of park plots, while 10 of 14 grazing treatment indicators were indicators of grazed plots. Seven of the 22 species were indicators of distinct combinations of habitat and grazing: 5 were indicators of grazed park plots, 1 of ungrazed park plots, and 1 of grazed tree plots.

\section{Discussion}

Scale

Grazing treatment and habitat affected species density at different grain sizes, showing the necessity of multiscaled assessments in 

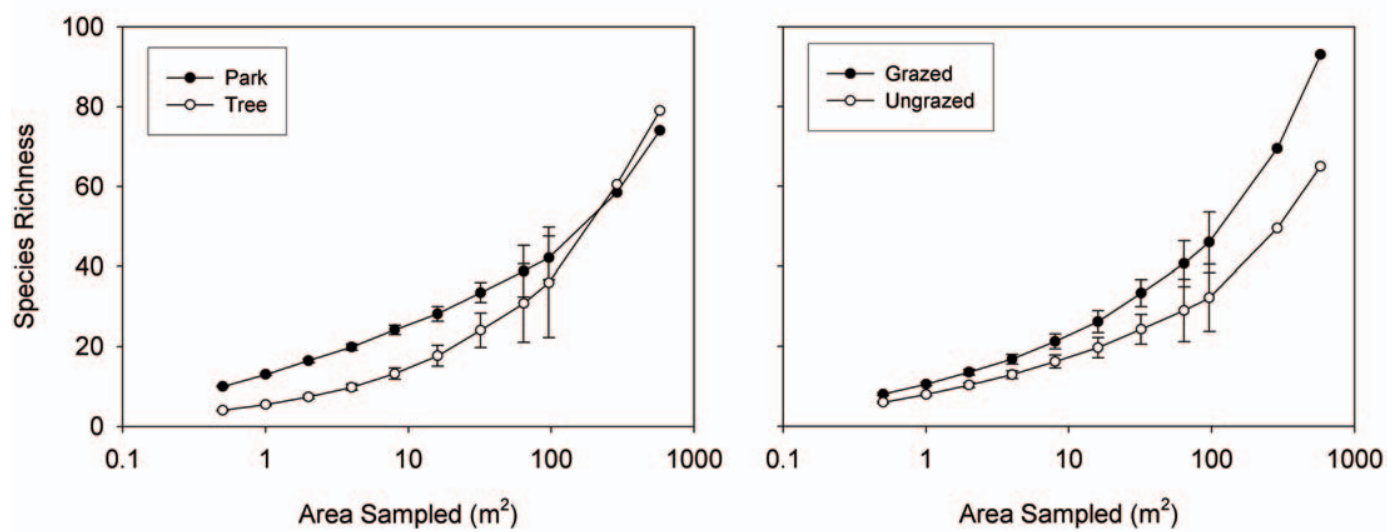

Fig. 3. Species-area curves (whisker bars indicate 95\% confidence intervals) for all species in park and tree habitats (left), and grazed and ungrazed areas (right). Note that the $x$-axes are log-transformed. Confidence intervals are not shown for the 2 largest grain sizes because of the low number of replicates $(n=2$ and 1, respectively).

examination of ecological hypotheses (Gross et al. 2000, Crawley and Harral 2001). Conservation and management decisions must explicitly account for the grain at which data have been collected and analyzed when plant community responses to treatments are evaluated.

Our sampling was conducted using small quadrats $\left(0.5 \mathrm{~m}^{2}\right)$ because we felt that ecological interactions such as competition and dispersal, which are important in structuring communities, would be strongest at these scales. However, species density differed significantly between habitats and between grazing treatments at all grains $\leq 4 \mathrm{~m}^{2}$, suggesting that future studies could use quadrats up to this size to detect differences in species density between treatments. Nested sampling techniques, such as modified Whittaker plots (Stohlgren et al. 1995), are also used to assess large extents and to develop species-area curves. But these techniques generally do not sample as intensively at larger grains, raising the possibility that rare or diminutive species will be missed. The optimal grain is a balance between the required resolution and the logistical constraints associated with sampling more, smaller quadrats.

Species-area curves did not level off after sampling $576 \mathrm{~m}^{2}$ in any treatment (Fig. 3). On average, based on the difference in species richness between the 2 largest grain sizes, a species was still being added for every $16 \mathrm{~m}^{2}$ of ground sampled. An estimate of the true species richness of these treatments would clearly require sampling of even larger areas.

\section{Grazing}

Livestock grazing might be expected to increase species density at small grain sizes by increasing the patchiness (spatial heterogeneity) of the vegetation and therefore the rate of species turnover. Many studies have examined grazing effects at small grains, but the results are inconclusive: some have reported increased richness in grazed areas (Rambo and Faeth 1999, Stohlgren et al. 1999, Pykala 2004), while others found no effect of grazing (Guenther et al. 2004, Bakker and Moore 2007) or reduced richness in grazed areas (reviewed by Fleischner 1994). These conflicting reports may reflect differences in productivity, environmental conditions, parent material, soil type, kind of livestock, and season of grazing (Johnson 1956, Olff and Ritchie 1998).

We found that grazing increased species density at small grains (Fig. 3), but this effect was small compared to the differences in species density between habitats. Furthermore, although grazed areas did contain more exotic species, they did not differ in substrate composition, litter depth, or plant cover. Overall, grazing effects were minimal at small grains. This result is surprising given that the exclosure was in place for 93 years and vegetation might therefore be expected to differ more strongly. However, this result may relate to the very low livestock grazing intensity outside the exclosure in recent years (Bakker and Moore 2007).

Studies of grazing effects are less common at large grain sizes. Stohlgren et al. (1999) found 

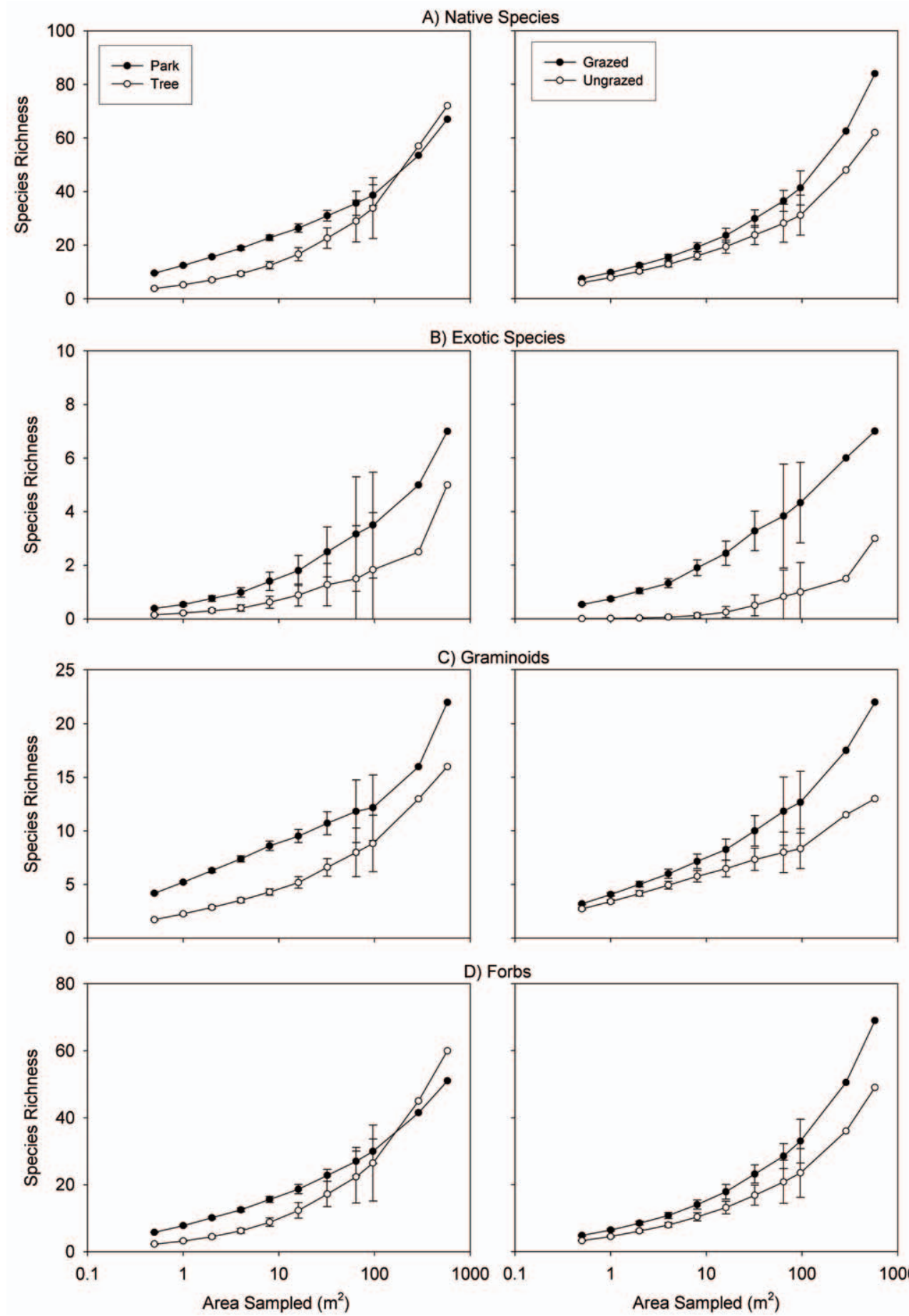

D) Forbs

Fig. 4. Species-area curves (whisker bars indicate 95\% confidence intervals) for (A) native species, (B) exotic species, (C) graminoid species, and (D) forb species in park and tree habitats (left), and grazed and ungrazed areas (right). Note that the $x$-axes are log-transformed and that the scale of the y-axis differs among rows. Confidence intervals are not shown for the 2 largest grain sizes because of the low number of replicates ( $n=2$ and 1, respectively). 
TABLE 2. Indicator species associated with habitats and grazing treatments at Fry Park, northern Arizona.

\begin{tabular}{|c|c|c|c|c|c|c|}
\hline \multirow[b]{2}{*}{ Species } & \multirow[b]{2}{*}{ Habitat IVa } & \multirow[b]{2}{*}{ Grazing IV } & \multicolumn{2}{|c|}{ Parkb } & \multicolumn{2}{|c|}{ Tree $^{b}$} \\
\hline & & & Grazed & Ungrazed & Grazed & Ungrazed \\
\hline Agropyron desertorum & & $25.0 \mathrm{G}$ & $1.6-25$ & - & - & - \\
\hline Arenaria fendleri & $57.3 \mathrm{P}$ & & $3.7-85$ & $1.7-58$ & $0.0-2$ & - \\
\hline Artemisia carruthii & $49.8 \mathrm{P}$ & & $1.4-39$ & $1.9-68$ & $0.2-12$ & $0.2-20$ \\
\hline Blepharoneuron tricholepis & & $26.3 \mathrm{U}$ & $0.2-6$ & $1.0-36$ & $0.5-10$ & $1.5-26$ \\
\hline Bouteloua simplex & & $26.6 \mathrm{G}$ & $0.6-27$ & - & - & - \\
\hline Carex geophila & $41.4 \mathrm{~T}$ & & $0.4-14$ & $0.2-22$ & $4.3-67$ & $0.4-28$ \\
\hline Chamaesyce serpyllifolia & $31.9 \mathrm{P}$ & $42.8 \mathrm{G}$ & $0.1-69$ & $0.0-15$ & $0.0-20$ & $0.0-5$ \\
\hline Elymus elymoides & $28.8 \mathrm{~T}$ & $35.5 \mathrm{G}$ & $0.7-19$ & $0.6-20$ & $1.7-66$ & $0.3-35$ \\
\hline Erigeron divergens & $50.7 \mathrm{P}$ & $27.3 \mathrm{G}$ & $0.7-67$ & $0.5-39$ & $0.1-8$ & $0.0-1$ \\
\hline Erigeron flagellaris & $26.6 \mathrm{P}$ & $31.5 \mathrm{G}$ & $3.3-46$ & - & $0.5-17$ & - \\
\hline Koeleria macrantha & $27.4 \mathrm{P}$ & & $1.1-40$ & $1.4-29$ & $0.0-1$ & $0.0-1$ \\
\hline Lupinus argenteus & & $35.2 \mathrm{U}$ & $0.0-2$ & $0.6-36$ & - & - \\
\hline Monroa squarrosa & & $31.8 \mathrm{G}$ & $0.1-63$ & - & $0.0-1$ & - \\
\hline Muhlenbergia minutissima & $40.9 \mathrm{P}$ & & $0.2-52$ & $0.1-46$ & $0.1-14$ & $0.0-24$ \\
\hline Muhlenbergia montana & $38.9 \mathrm{P}$ & $49.8 \mathrm{U}$ & $0.6-7$ & $8.5-81$ & $0.1-2$ & $0.9-26$ \\
\hline Muhlenbergia wrightii & $30.1 \mathrm{P}$ & & $4.1-46$ & $8.7-51$ & $0.3-5$ & $0.0-2$ \\
\hline Pascopyrum smithii & $39.8 \mathrm{P}$ & $29.9 \mathrm{G}$ & $4.0-40$ & - & $0.0-1$ & - \\
\hline Poa fendleriana & $57.8 \mathrm{P}$ & & $4.0-47$ & $4.9-82$ & $1.2-23$ & $0.2-8$ \\
\hline Polygonum douglasii & $36.6 \mathrm{P}$ & $40.9 \mathrm{G}$ & $0.4-73$ & $0.1-29$ & $0.1-29$ & $0.1-25$ \\
\hline Portulaca oleracea & & $25.0 \mathrm{G}$ & $0.1-47$ & $0.0-2$ & $0.0-5$ & - \\
\hline Solidago velutina & & $25.9 \mathrm{U}$ & - & $0.3-37$ & $0.0-1$ & $0.7-41$ \\
\hline Sporobolus interruptus & $63.6 \mathrm{P}$ & & $19.1-94$ & $11.1-65$ & - & - \\
\hline
\end{tabular}

Indicator value (IV). All indicator species have mean indicator values $\geq 25$ (shown) and combined $P$ value $<0.05$ (not shown). Letters after the IV indicate the treatment of which the species was an indicator (habitat: $\mathrm{P}=$ park; $\mathrm{T}=$ tree; grazing: $\mathrm{G}=$ grazed; $\mathrm{U}=$ ungrazed). Note that species can be indicators of either or both treatments.

or both treatments.
bCover data are the mean aerial cover and the percentage of quadrats on which a species occurred in a treatment combination. For example, A. desertorum had a mean cover of $1.6 \%$ and occurred on $25 \%$ of quadrats within park grazed plots. A dash indicates that a species did not occur in that treatment combination.

no difference in species richness between 1000$\mathrm{m}^{2}$ grazed and ungrazed sites. We were unable to detect statistically significant differences between grazing treatments at grains $>32 \mathrm{~m}^{2}$, though there was a tendency for grazing treatments to diverge at larger grains (Fig. 3). However, we have presented results from a single grazing exclosure; additional multiscaled assessments of grazing effects are clearly warranted.

Ten species were indicators of grazed areas. Included in this list are a number of diminutive annuals (e.g., Polygonum douglasii Greene, Chamaesyce serpyllifolia [Pers.] Small) and biennials (e.g., Erigeron flagellaris A. Gray, Erigeron divergens Torr. \& A. Gray) that were also indicators of park areas. These species are able to persist likely because they are too small to be grazed and/or because they can rapidly colonize grazing-induced disturbances.

All larger-statured indicators of grazed areas were grasses, and their indicator status could often be explained by reference to their biology. For example, Pascopyrum smithii (Rydb.) A. Löve is strongly rhizomatous, while Elymus elymoides (Raf.) Swezey has long, sharp awns that protect it from grazing after flowering. Elymus elymoides also colonizes sites quickly and was more common in grazed than ungrazed areas of the Hill plots between 1921 and 1941 (Arnold 1950), suggesting that it is a stable indicator of grazed areas. Agropyron desertorum (Fisch. ex Link) Schult., an exotic species, was commonly seeded into grazed areas to increase forage for livestock.

Indicators of ungrazed plots included bunchgrasses (Muhlenbergia montana [Nutt.] Hitchc. and Blepharoneuron tricholepis [Torr.] Nash) that are palatable to cattle (Johnson 1956, Smith 1967) and tall, showy forbs (Lupinus argenteus Pursh and Solidago velutina DC.) whose aboveground vegetative parts may be susceptible to grazing damage due to their taller stature. Muhlenbergia montana was also an indicator of park areas, suggesting that it has a more narrowly defined set of preferred environmental conditions than the other indicators of ungrazed areas.

\section{Habitat}

Based on all 5 Hill plots, Bakker and Moore (2007) concluded that differences in overstory abundance explained more of the variation in understory herbaceous vegetation than did grazing treatments. Our findings at small grain 
sizes are consistent with their conclusion, even though our study was conducted at a single site in a different year and with a different sampling methodology. Other studies have also reported fewer understory species in treed areas than in open or grassland areas (Arnold 1950, McConnell and Smith 1970, Naumburg and DeWald 1999, Crawley and Harral 2001). Differences in species density between habitats declined more slowly with increasing grain size than those between grazing treatments, though park and tree habitats never differed at grains $>32 \mathrm{~m}^{2}$. Crawley and Harral (2001) reported that woodlands exhibited stronger scale-dependent changes in the slope of the species-area relationship, which was also the case here: tree plots contained fewer species at small grains but accumulated species more rapidly than park plots.

The only indicators of tree plots were 2 perennial graminoids, Carex geophila Mack. and E. elymoides. Naumburg and DeWald (1999) observed that the presence of both of these species was positively related to forest structure, while Naumburg et al. (2001) concluded that E. elymoides was less affected by experimental shading than 3 other dominant grass species. Elymus elymoides was more common in tree than park plots before 1941, though it declined in abundance as the overstory increased in dominance (Arnold 1950).

Thirteen species were indicators of park areas, possibly due to the high light availability (McConnell and Smith 1970) or to other edaphic variables within the park habitat, including increased water during snow runoff, frost pocketing, and differences in soils and fire regime. Several of these species were also identified as indicators of park areas in earlier studies (Arnold 1950, Bakker 2005). Sporobolus interruptus Vasey is of particular interest as it is locally abundant but endemic to a small region of northern Arizona. Poa fendleriana (Steud.) Vasey does not appear to be reacting to light availability in the park, as Naumburg and DeWald (1999) did not detect a relationship between the presence or absence of this species and forest structure. Similarly, Koeleria macrantha (Ledeb.) Schult. was an indicator of park areas but was less affected by experimental shading than 3 other common grass species (Naumburg et al. 2001).

Vegetative differences between habitats likely affect livestock grazing patterns. Compositional differences between habitats influence species selection by livestock, and the very large differences in forage quantity mean that most grazing likely occurs in the park areas. More detailed analyses of these patterns, however, were beyond the scope of this project.

\section{Conclusions}

We conclude that habitat has a stronger effect than livestock grazing on the herbaceous understory vegetation of this southwestern ponderosa pine-bunchgrass ecosystem, particularly at small grain sizes. Our results also suggest that grazing effects tend to be more pronounced at larger grain sizes, though studies with replicate grazing treatments would be required to verify this conclusion. Evaluations of plant community response to treatments must explicitly account for the scale at which data have been collected and analyzed. Furthermore, particular plant species are indicators of habitat, grazing treatment, or unique treatment combinations. This knowledge contributes to our understanding of factors that control plant abundance and diversity and enables more informed conservation and management. For example, treatment effects could be more efficiently monitored by focusing on those species identified as indicators of that treatment.

Logistical constraints prevented this study from being replicated at multiple sites. Future studies could assess the generality of these results by conducting similar studies at additional sites. The long-term nature of the grazing treatments ( $>90$ years) was a unique element of this study, and short- and long-term responses to grazing exclusion may differ. Examination of this question would require the development of species-area curves for sites that differ in time since grazing exclusion.

\section{ACKNOWLEDGMENTS}

We thank the Coconino National Forest for maintaining the exclosure fences, permitting us to collect data at the site, and providing us with grazing records. The Ecological Restoration Institute provided financial and logistical support of this work, which constituted F. Rudebusch's undergraduate senior project. Susan Nyoka, Rob Hastings, Teresa Dekoker, Sanjeev Panday, Kristen Pearson, and Danielle Gift ably assisted with fieldwork. Nancy Huntly, Christian Torgersen, Rick Gill, and several anonymous 
reviewers read and commented on earlier drafts of this paper. J.D. Bakker was supported in part by the University of Washington.

\section{Literature Cited}

Allen, C.D., M. Savage, D.A. Falk, K.F. Suckling, T.W Swetnam, T. Schulke, P.B. Stacey, P. Morgan, M. HofFman, AND J.T. KLINGEL. 2002. Ecological restoration of southwestern ponderosa pine ecosystems: a broad perspective. Ecological Applications 12:1418 1433.

Anderson, M.J. 2001. A new method for non-parametric multivariate analysis of variance. Austral Ecology 26:32-46.

ARNOLD, J.F. 1950. Changes in ponderosa pine-bunchgrass ranges in northern Arizona resulting from pine regeneration and grazing. Journal of Forestry 48: $118-126$.

BAKKER, J.D. 2005. Long-term vegetation dynamics of southwestern ponderosa pine forests. Doctoral dissertation, Northern Arizona University, Flagstaff, AZ.

2008. Increasing the utility of indicator species analysis. Journal of Applied Ecology 45:1829-1835.

BaKKer, J.D., AND M.M. MoORE. 2007. Controls on vegetation structure in southwestern ponderosa pine forests, 1941 and 2004. Ecology 88:2305-2319.

CARMEL, Y., AND R. KADMON. 1999. Effects of grazing and topography on long-term vegetation changes in a Mediterranean ecosystem in Israel. Plant Ecology 145:243-254.

ColwelL, R.K., C.X. MAO, AND J.Chang. 2004. Interpolating, extrapolating, and comparing incidence-based species accumulation curves. Ecology 85:2717-2727.

Condit, R., S.P. Hubbell, J.V. Lafrankie, R. Sukumar, N. Manokaran, R.B. Foster, and P.S. Ashton. 1996. Species-area and species-individual relationships for tropical trees: a comparison of three 50-ha plots. Journal of Ecology 84:549-562.

CoOP, J.D., AND T.J. Givnish. 2007. Gradient analysis of reversed treelines and grasslands of the Valles Caldera, New Mexico. Journal of Vegetation Science 18:43-54.

CoOper, C.F. 1960. Changes in vegetation, structure, and growth of southwestern pine forests since white settlement. Ecological Monographs 30:129-164.

Courtois, D.R., B.L. Perryman, And H.S. Hussein. 2004 Vegetation change after 65 years of grazing and grazing exclusion. Journal of Range Management 57:574-582.

Covington, W.W., and M.M. Moore. 1994. Postsettlement changes in natural fire regimes and forest structure: ecological restoration of old-growth ponderosa pine forests. Journal of Sustainable Forestry 2:153-181.

Crawley, M.J., and J.E. Harral. 2001. Scale dependence in plant biodiversity. Science 291:864-868.

DuFrÊNE, M., AND P. LEGENDRE. 1997. Species assemblages and indicator species: the need for a flexible asymmetrical approach. Ecological Monographs 67:345366.

FLeischner, T.L. 1994. Ecological costs of livestock grazing in western North America. Conservation Biology 8:629-644.

GotelLi, N.J., AND R.K. CoLwELL. 2001. Quantifying biodiversity: procedures and pitfalls in the measurement and comparison of species richness. Ecology Letters 4:379-391.
Green, J.L., J. Harte, And A. Ostling. 2003. Species richness, endemism and abundance patterns: tests of two fractal models in a serpentine grassland. Ecology Letters 6:919-928.

Gross, K.L., M.R. Willig, L. Gough, R. InOuYe, AND S.B. Cox. 2000. Patterns of species density and productivity at different spatial scales in herbaceous plant communities. Oikos 89:417-427.

Guenther, D., T.J. Stohlgren, and P. Evangelista. 2004. A comparison of a near-relict site and a grazed site in a pinyon-juniper community in the Grand StaircaseEscalante National Monument, Utah. Pages 153-162 in C. van Riper III and K.L. Cole, editors, The Colorado Plateau: cultural, biological, and physical research. University of Arizona, Tucson, AZ.

Hargrove, W.W., and J. Pickering. 1992. Pseudoreplication: a sine qua non for regional ecology. Landscape Ecology 6:251-258.

Hurlbert, S.H. 1984. Pseudoreplication and the design of ecological field experiments. Ecological Monographs 54:187-211.

Johnson, W.M. 1956. The effect of grazing intensity on plant composition, vigor, and growth of pine-bunchgrass ranges in central Colorado. Ecology 37:790-798.

Laughlin, D.C., M.M. Moore, J.D. Bakker, C.A. Casey, J.D. Springer, P.Z. Fulé, and W.W. Covington. 2006. Assessing targets for the restoration of herbaceous vegetation in ponderosa pine forests. Restoration Ecology 14:548-560.

Loeser, M.R., T.E. CREwS, AND T.D. SISK. 2004. Defoliation increased above-ground productivity in a semi-arid grassland. Journal of Range Management 57:442-447.

MagurRan, A.E. 2004. Measuring biological diversity. Blackwell, Oxford, United Kingdom.

McArdLe, B.H., AND M.J. Anderson. 2001. Fitting multivariate models to community data: a comment on distance-based redundancy analysis. Ecology 82:290297.

McConnelL, B.R., AND J.G. SMith. 1970. Response of understory vegetation to ponderosa pine thinning in eastern Washington. Journal of Range Management 23:208-212.

McCune, B., AND J.B. GRace. 2002. Analysis of ecological communities. MJM Software Design, Gleneden Beach, OR.

Milchunas, D.G. 2006. Responses of plant communities to grazing in the southwestern United States. General Technical Report RMRS-GTR-169, USDA Forest Service, Rocky Mountain Research Station, Fort Collins, $\mathrm{CO}$.

Miller, G., N. Ambos, P. Boness, D. Reyher, G. RobertSON, K. Scalzone, R. Steinke, and T. Subirge. 1995. Terrestrial ecosystem survey of the Coconino National Forest. USDA Forest Service, Southwestern Region.

Moore, M.M., C.A. Casey, J.D. Bakker, J.D. Springer, P.Z. Fulé, W.W. Covington, and D.C. Laughlin. 2006. Herbaceous response to restoration treatments in a ponderosa pine forest, 1992-2004. Rangeland Ecology and Management 59:135-144.

Moore, M.M., AND D.A. DeITER. 1992. Stand density index as a predictor of forage production in northern Arizona pine forests. Journal of Range Management 45:267271.

Naumburg, E., AND L.E. DeWaLd. 1999. Relationships between Pinus ponderosa forest structure, light characteristics, and understory graminoid species presence 
and abundance. Forest Ecology and Management 124:205-215.

Naumburg, E., L.E. DeWaLd, And T.E. Kolb. 2001. Shade responses of five grasses native to southwestern Pinus ponderosa forests. Canadian Journal of Botany 79: 1001-1009.

Oesterheld, M., AND O.E. SALA. 1990. Effects of grazing on seedling establishment: the role of seed and safesite availability. Journal of Vegetation Science 1:353358.

OKSANEn, L. 2001. Logic of experiments in ecology: is pseudoreplication a pseudoissue? Oikos 94:27-38.

OlfF, H., AND M.E. RitchiE. 1998. Effects of herbivores on grassland plant diversity. Trends in Ecology and Evolution 13:261-265.

Pykala, J. 2004. Cattle grazing increases plant species density of most species trait groups in mesic seminatural grasslands. Plant Ecology 175:217-226.

RAMBO, J.L., aNd S.H. FaETH. 1999. Effects of vertebrate grazing on plant and insect community structure. Conservation Biology 13:1047-1054.

Ruthven, D.C., III. 2007. Grazing effects on forb diversity and abundance in a honey mesquite parkland. Journal of Arid Environments 68:668-677.
SмiтH, D.R. 1967. Effects of cattle grazing on a ponderosa pine-bunchgrass range in Colorado. Technical Bulletin 1371, U.S. Department of Agriculture, Washington, DC.

Stohlgren, T.J., M.B. Falkner, and L.D. Schell. 1995. A modified-Whittaker nested vegetation sampling method. Vegetatio 117:113-121.

Stohlgren, T.J., L.D. Schell, and B. Vanden Heuvel. 1999. How grazing and soil quality affect native and exotic plant diversity in Rocky Mountain grasslands. Ecological Applications 9:45-64.

[USDA-NRCS] United States Department of Agriculture, Natural Resources Conservation Service. 2006. The PLANTS Database, National Plant Data Center, Baton Rouge, LA; [cited February 2006]. Available from: http://plants.usda.gov

[USFS] United States Forest Service. 2005. Annual operating instructions for Windmill Allotment. Letter from G. Waldrip to Morrison Ranch on April 27. USDA Forest Service, Coconino National Forest, Flagstaff, AZ.

Received 31 December 2008 Accepted 2 March 2010 